\title{
Discount Coupons in Rural Markets
}

\author{
Ronald B. Larson \\ Mid-America Consultants International \\ Jean Kinsey \\ University of Minnesota
}

Discount coupons are popular tools for communicating messages and promoting products to consumers. In the US, many rural residents receive fewer certificates offering price discounts than people living in urban markets. Five store-intercept surveys in two rural communities were analyzed to learn more about rural coupon users. During the 28-year time span covered by the surveys, coupon use in these communities remained steady. The proportions of heavy coupon redeemers and the amount of active searching for coupons were lower than in national surveys, probably from limited coupon availability. Manufacturers should consider expanding their coupon distribution in rural areas.

Keywords: Sales Promotion, Store-Intercept Survey, Regionality, Couponing, Free-Standing Inserts

\section{INTRODUCTION}

For more than a century, consumer packaged goods firms have used discount coupons to promote their products directly to consumers. These certificates offer price discounts on specific items and are important marketing tools for food, pet supplies, and health and beauty care. Besides providing discounts, coupons have advertising, reminding, and utility effects (Larson, 1991; 1992; 1994), which makes them valuable for marketing communication. US manufacturers spent more than $\$ 5$ billion to distribute and redeem coupons in 2018. About 94 percent of the coupons distributed were in free-standing inserts (FSIs), booklets usually in Sunday newspapers that are primarily advertisements with manufacturer coupons, and about 2 percent were digital or electronic coupons (NCH Marketing Services, 2019). Manufacturers choose where to distribute their paper coupons and often deliver fewer coupons in rural areas than in urban markets. Explanations of these geographic differences center around two questions: 1) Did manufacturers reduce distribution in rural areas when scanning data was introduced because few rural stores were included in scanning data samples and continue using this distribution scheme? and 2) Are coupons less effective in rural areas because rural residents dislike coupons or choose not to redeem them? Comparisons over time will help address the first question. Five consumer intercept surveys in rural markets will help explore the second hypothesis. This research will consider why rural consumers receive fewer coupons. To set the stage for this analysis, reviews of historical coupon trends and of prior research on coupon users start this paper. 


\section{Coupon Trends}

For many years, the number of coupons distributed by US marketers and the number redeemed by consumers increased (Figure 1). Manufacturer coupons are redeemable at any retailer while store (i.e., inad) coupons are only good at one retailer (and some manufacturers sponsor store coupons). Household use of coupons increased as distribution grew, from 58 percent in 1971 and 65 percent in 1975 to 79 percent in 1984 and 77 percent in 1988 (Nielsen Clearing House, 1986; Manufacturers Coupon Center, 1989). Manufacturer coupon distribution reached 310 billion in 1992 and peaked at 332 billion in 2010 (Nielsen Clearing House/Valassis reports). US coupon distribution declined to 257 billion coupons in 2018.

FIGURE 1

ANNUAL US MANUFACTURER COUPON DISTRIBUTION FROM 1965 TO 2018

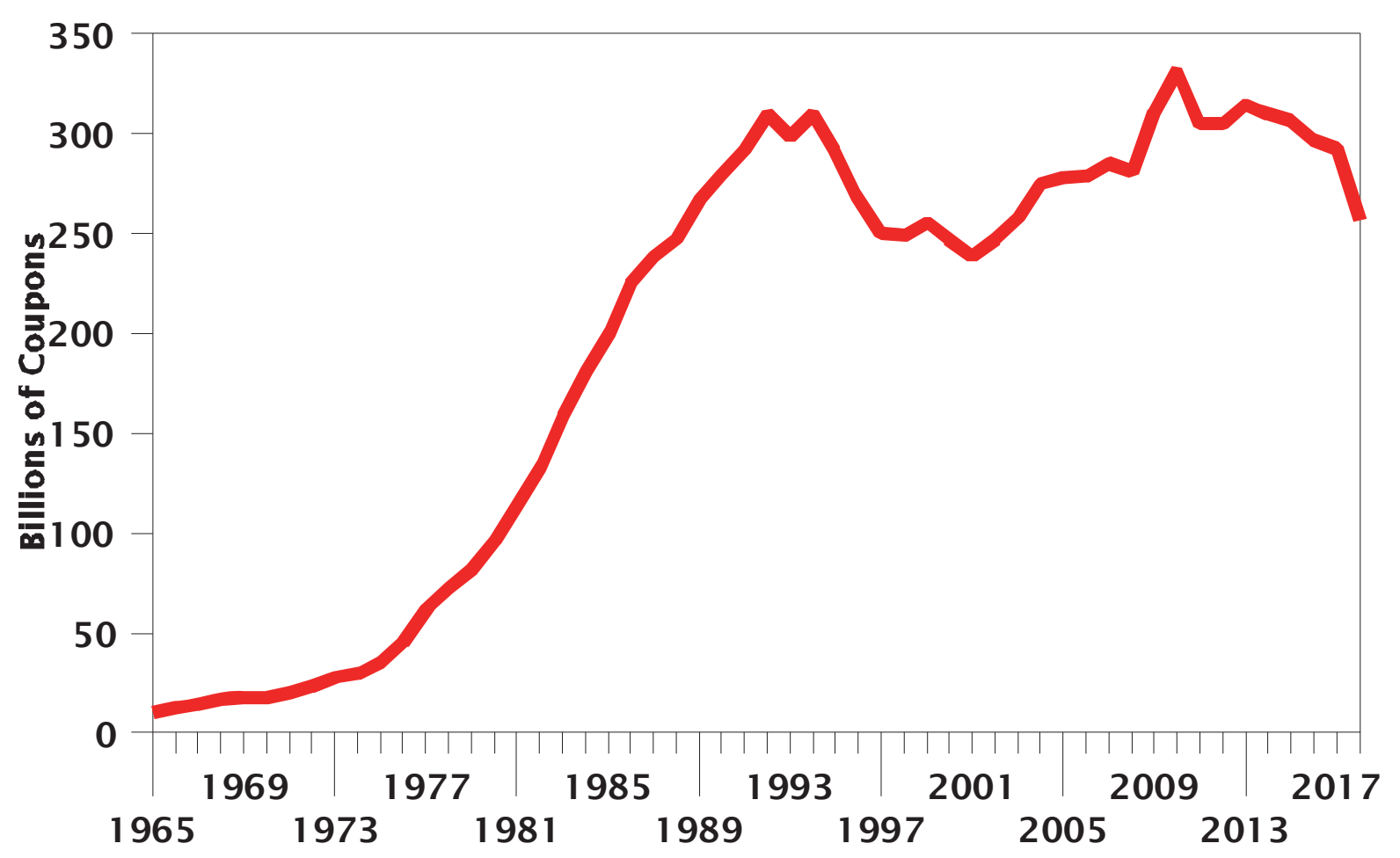

(Data Source: Nielsen Clearing House/Valassis reports)

Annual coupon redemptions for consumer packaged goods had a different trajectory (Figure 2). The number redeemed in the US declined from 7.7 billion in 1992 to 1.7 billion in 2018 (Nielsen Clearing House/Valassis estimates). The percentage redeemed fell from about 4.0 percent in 1980 to about 0.7 percent in 2018. Many factors probably contributed to this change, including a shift in the mix of brands that distributed coupons, a decrease in retail matching or "bonus" coupon promotions (e.g., doubling, tripling, or quadrupling coupon values), an increase in redemption restrictions (e.g., multiple purchase requirements that require buying several items for the discount rose from 12 percent in 1992 to 29 percent in 2012), and a decrease in the time between when coupons were distributed and when the offers expired (e.g., the average of about 4.0 months in 1992 fell to 2.2 months by 2012). Although multiple purchase restrictions and short durations may lower a manufacturer's couponing costs, they may limit consumer enthusiasm for clipping coupons. Recent research found that these restrictions could also lower consumer attitudes toward the company (Trump, 2016). 
FIGURE 2

ANNUAL US MANUFACTURER COUPON REDEMPTIONS FROM 1980 TO 2018

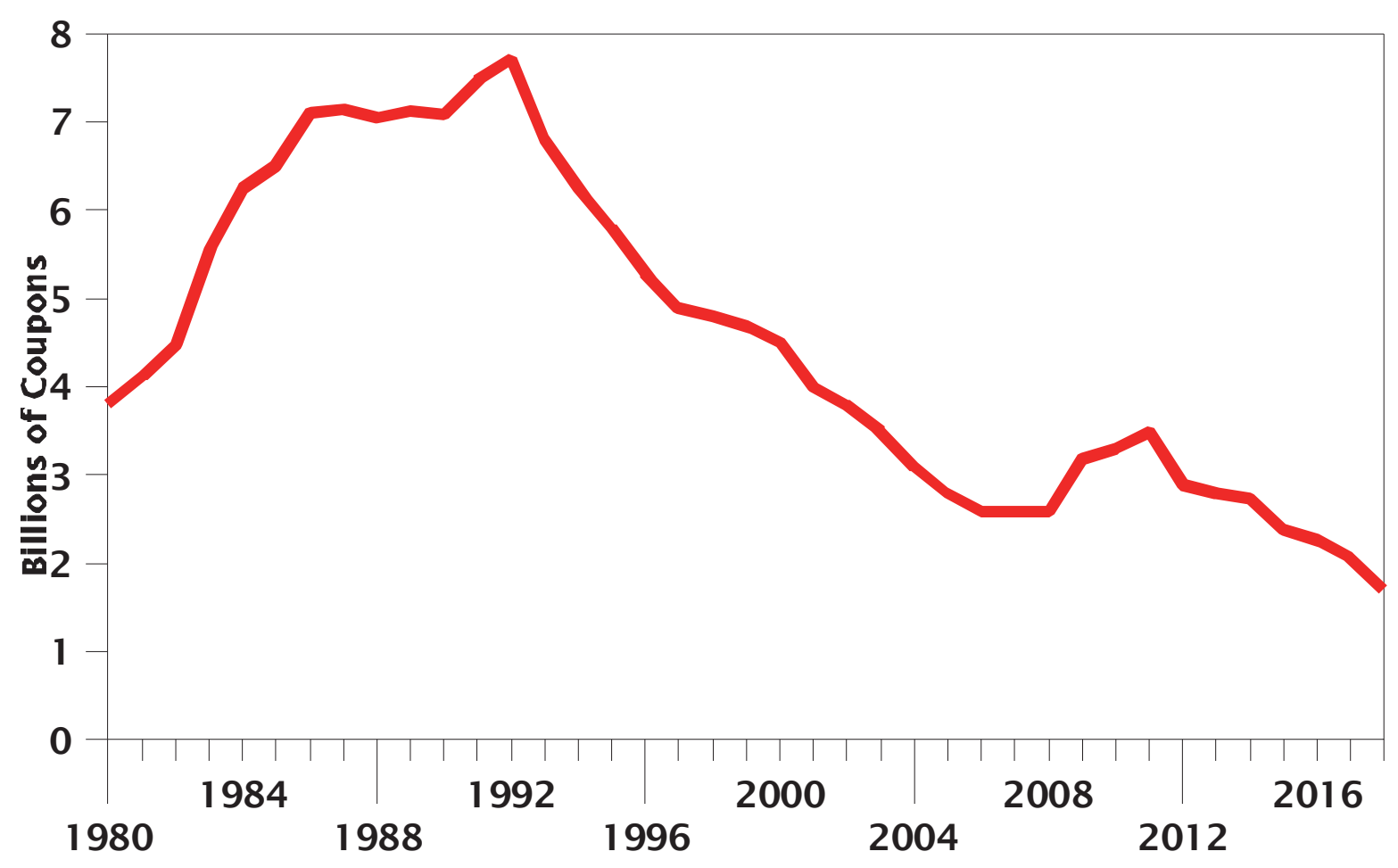

(Data Source: Nielsen Clearing House/Valassis reports)

\section{Coupon Benefits}

The power of coupons to boost sales was shown to marketers when weekly retailer scanning data became available in the 1980s. One executive said the scanner data created an explosion of learning about promotions (Gibson, 1991). Many consumer packaged goods firms had tracked their sales with bimonthly retail sales or 4-week warehouse withdrawals that did not reveal the sales spikes during the weeks immediately after coupon events. As scanning data became the primary marketing data source, firms started setting their annual goals using this data and rewarded product managers if market share objectives were surpassed. Early scanner data was based on a sample of stores in selected metropolitan areas. Few rural retailers had the technology to scan universal product codes at the checkout. One author worked in the industry at this time and noted that product managers reduced marketing spending in rural areas because it would not boost the scanner-measured market shares. Market distribution lists concentrated coupons in the metropolitan areas that were part of the scanning data sample.

Some marketing managers understood that coupons had other effects besides price discounts and believed the sum of all the effects make coupon events profitable. Field studies found that the net revenue gains from the incremental sales during the first 12 weeks after a coupon event covered more than 79 percent of the coupon promotion costs while the net revenue from the sales gains after trade promotions (e.g., incentives for feature ads and displays in stores) covered about 35 percent of the promotion costs during the same period (Promotion Decisions, 1997). FSIs became the dominant coupon distribution vehicle, perhaps because the advertising value of paper-distributed coupons may be higher than the advertising value of coupons distributed electronically. Because urban newspaper circulation is often lower in rural areas, local newspapers and cooperative direct mail could supplement distribution in rural markets.

A surge of public criticism of coupons also occurred in the 1980s (e.g., Nigut, 1981; Uhl, 1982). A survey of 41 executives at 10 companies found that most believed coupons were ineffective (Bucklin \& 
Gupta, 1999). Some managers believed their primary benefit was as a sales presentation tool, helping to stimulate store participation in trade promotions. These marketers preferred reducing event costs by limiting distribution and by adding restrictions. During the 1980s and 1990s, many firms, including Colgate, General Foods, Kraft USA, Procter and Gamble, and General Mills, announced they were reducing their coupon spending (Lipman, 1987; 1989; Deveny \& Bibson, 1994). Procter and Gamble tested reducing coupons in one market and decided to resume couponing in that market even before the planned test was completed (Slater, 2001). The FSI industry also developed the ability to customize inserts by neighborhood, making it possible for managers to target coupons at specific areas (with as many as 100,000 zones across the US).

\section{COUPON DISTRIBUTION IN RURAL MARKETS}

There is little data on how coupon distribution varies by level of urbanization. In the mid-1980s, NPD Group (1986) analyzed the purchases with manufacturer coupons in 15 product categories by a national diary panel of US consumers. Shoppers were sorted into two groups, those living in counties with populations of at least 150,000 and those living in counties with populations less than 150,000. Consumers in the more populated counties bought 32 percent of their items with coupons. Those in the rural counties purchased 21 percent on coupon deal. NPD Group concluded that coupon levels were more than 50 percent higher in urban counties.

Kantar Media provided marketing intelligence to clients on what coupons were distributed in each market. They totaled and mapped the FSI coupons distributed during 2015 by county (Kantar Media, 2016). On average, about 880 FSI coupons were distributed per person in 2015. Some US counties received more than 5000 coupons per person and many others, typically rural areas, received less than 100 FSI coupons per person (Figure 3). Like the NPD Group study, Kantar Media concluded that coupon

distribution had an urban skew. These two studies raise the question of why manufacturers are targeting their coupons at urban communities. 
FIGURE 3

FSI COUPON DISTRIBUTION PER PERSON BY COUNTY IN 2015

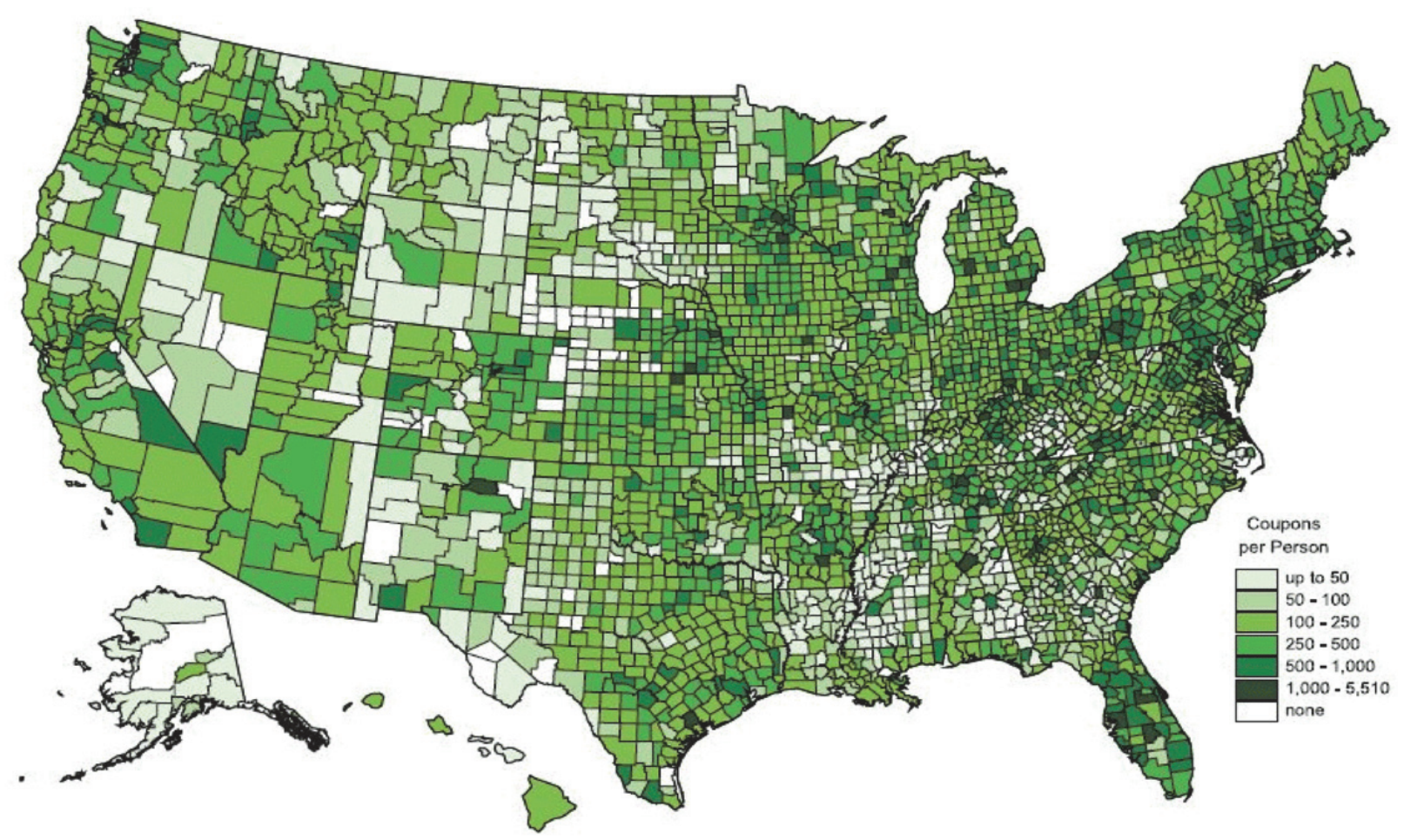

(Source: Kantar Media, 2016, Reproduced with permission)

There are several possible explanations why coupon distribution has been more intense in urban markets for at least 30 years. Manufacturers may still be using the market distribution lists that were developed during the 1980s when scanner data had limited coverage. It is also possible that attitudes toward coupons or coupon usage are different in rural areas and marketers have adjusted to these differences. The next section considers the results from four industry surveys that compared urban and rural areas.

\section{PROFILES OF COUPON USERS}

Many surveys asked consumers about their interest in or use of coupons. Most implicitly assumed that demographics provide key insights into coupon redeemers and did not test for significant differences. Four surveys, conducted by US organizations that provide services to the industry, compared coupon usage in urban or rural areas. A 1984 national telephone survey found that about 78 percent of those living in counties with populations of at least 150,000 said they used coupons and about 26 percent redeemed at least five coupons per week (Nielsen Clearing House 1985). About 80 percent of those living in counties with populations less than 150,000 used coupons and about 23 percent redeemed at least five per week. In 1984, there was little variation between the two markets.

The Newspaper Advertising Bureau published coupon user profiles. In 1985, about 70 percent used coupons in counties with more than 150,000 people and about 64 percent used coupons in counties with less than 150,000 people. In 1986, about 67 percent used coupons in urban counties and 64 percent in rural counties (Newspaper Advertising Bureau, 1987). These results suggest that a gap in coupon use may have started between urban and rural consumers. This was also when scanning data started becoming more important for marketing decisions.

A national telephone survey in 1988 found a greater difference between the counties (Manufacturers Coupon Center, 1989). About 79 percent of those living in counties with populations of at least 150,000 
said they used coupons and about 32 percent redeemed at least nine coupons per week. About 73 percent of those in rural counties used coupons and about 19 percent redeemed at least nine per week. None of the industry coupon surveys conducted after 1988 compared the urban and rural markets.

This study will use store-intercept surveys, fielded in two rural communities, to examine coupon usage, attitudes toward coupons, and active searching for coupons. The first survey was done in 1984 before there was evidence of a wide gap between urban and rural markets. Because the surveys are spread over 28 years, shifts in the profile of rural coupon users can be identified. The questions to be addressed by these surveys include: 1) Who redeems coupons in rural areas? 2) Have coupon attitudes or usage in rural areas changed over time? and 3) Are attitudes or behaviors involving coupons different in rural areas? Multivariate analyses will help identify significant relationships between coupon usage and the attitude, behavior, and demographic measures. National surveys will serve as benchmarks to identify any unique characteristics of rural coupon users.

The first national survey suggested that coupon use tended to increase with household size and with weekly grocery expenditures (Nielsen Clearing House, 1984). Whites were slightly more likely to be users. Income levels were not strongly linked with coupon use. This survey asked people how prices would change if coupons ended. About 20 percent thought prices would go up, 20 percent thought prices would decline, 50 percent said prices would stay the same, and 10 percent did not know. A Manufacturers Coupon Center survey, conducted in 1988, concluded that coupon use increased with household size and with weekly grocery spending. Whites were more likely to be users than nonwhites. Income had a limited connection with coupon use. As education levels increased, the percentage using coupons tended to decrease slightly. About half of all shoppers, 63 percent of coupon users, reported that they actively searched for coupons. This compares with active searching by 57 percent or coupon users in 1980 (Nielsen Clearing House, 1980). A 1992 survey by CMS (1993) asked consumers if coupons save shoppers money (86 percent agreed and 11 percent disagreed) and if coupons raised product prices (38 percent agreed and 45 percent disagreed).

Thirteen academic studies, published since 1980, tested for significant relationships between demographics and coupon use (Table 1). A comparison across the 13 surveys reveals many inconsistencies in the demographic profiles based on being a coupon user or on the levels of coupon usage. Some studies found significant relationships and others did not. In a few cases, the relationships had different signs. The variations in the results could be due to sample differences, to changes over time, or to the limited ability of demographics to explain coupon use. Mittal (1994) cautioned researchers against the arbitrary use of demographics for targeting promotions and concluded that measures of psychological processes provide better predictions of coupon use and more insights into users.

Journal of Applied Business and Economics Vol. 21(6) 2019129 
TABLE 1

ACADEMIC SURVEYS OF COUPON USERS IN THE US

\begin{tabular}{|c|c|c|}
\hline Source & Location & Relationships with Demographics \\
\hline Mooty (1982) & Arkansas & $\begin{array}{l}\text { Marital status was not significant while the highest coupon usage was in families } \\
\text { with children who were not old enough for school. }\end{array}$ \\
\hline $\begin{array}{l}\text { Narasimhan } \\
(1984)\end{array}$ & $\begin{array}{l}\text { Diary Panel (no } \\
\text { location) }\end{array}$ & $\begin{array}{l}\text { Various combinations of income (nonlinear), female education, the presence of } \\
\text { children, and female employment were linked with coupon use in some product } \\
\text { categories, but not in the other categories. }\end{array}$ \\
\hline $\begin{array}{l}\text { Bawa \& } \\
\text { Shoemaker } \\
\text { (1987) }\end{array}$ & US (National) & $\begin{array}{l}\text { Heavier users were younger, had higher incomes, had more education, and lived } \\
\text { in urban markets. Household size, employment of wife, and the presence of } \\
\text { young children were not significant. }\end{array}$ \\
\hline $\begin{array}{l}\text { Meloy, } \\
\text { McLaughlin } \\
\text { \& Kramer } \\
(1988)\end{array}$ & New York & $\begin{array}{l}\text { Heavy coupon users were from larger households, had less education, were } \\
\text { older, were married, had more children, had neither very low nor high incomes, } \\
\text { and were homemakers (not employed outside the home). Asked if food prices } \\
\text { would decrease if coupons were eliminated ( } 20.5 \text { percent strongly agreed, } 18.8 \\
\text { percent agreed, } 18.6 \text { percent disagreed, and } 5.3 \text { percent strongly disagreed - the } \\
\text { rest were not sure). }\end{array}$ \\
\hline $\begin{array}{l}\text { Avery \& } \\
\text { Haynes } \\
(1991 ; 1992 \\
1996)\end{array}$ & Columbus, $\mathrm{OH}$ & $\begin{array}{l}\text { Coupon users were more likely to be married and to live with larger families. } \\
\text { Heavy coupon users were more likely to be employed full-time and have higher } \\
\text { incomes. }\end{array}$ \\
\hline $\begin{array}{l}\text { Godwin } \\
(1192)\end{array}$ & City in Kansas & $\begin{array}{l}\text { One-person households, nonwhites, unmarried individuals, and those spending } \\
\text { less in the store that day were less likely to use coupons while income, college } \\
\text { education, and wife's employment were not significant. }\end{array}$ \\
\hline $\begin{array}{l}\text { Cronovich, } \\
\text { Daneshvary } \\
\text { \& Schwer } \\
(1997)\end{array}$ & $\begin{array}{l}\text { City in Western } \\
\text { Region }\end{array}$ & $\begin{array}{l}\text { Shopping behaviors (i.e., active searching), employment, and ethnicity (e.g., } \\
\text { Blacks and Hispanics, but not Asians or Indians) were linked with coupon use. } \\
\text { Income, household size, age, and education were not significant. }\end{array}$ \\
\hline Mittal (1994) & One City & $\begin{array}{l}\text { Attitudinal measures such as the enjoyment of the redemption process and } \\
\text { perceived time costs were better predictors of coupon use than demographics. }\end{array}$ \\
\hline $\begin{array}{l}\text { Park \& } \\
\text { Gomez } \\
(2004)\end{array}$ & Eastern Region & $\begin{array}{l}\text { Gender and household size were significant predictors of paper coupon use. Age, } \\
\text { income, and employment were not significant. Behaviors such as reading the } \\
\text { Sunday newspaper and scanning the papers for specials were also significant } \\
\text { (i.e., part of active searching). }\end{array}$ \\
\hline $\begin{array}{l}\text { Colombo, } \\
\text { Bawa, \& } \\
\text { Srinivasan } \\
(2003)\end{array}$ & $\begin{array}{l}\text { City in } \\
\text { Southwest }\end{array}$ & $\begin{array}{l}\text { Formed consumer segments based on differences in coupon proneness by } \\
\text { coupon type (e.g., direct mail coupons vs. FSI coupons). Did not ask subjects } \\
\text { about demographics. }\end{array}$ \\
\hline $\begin{array}{l}\text { Clark, Zboja } \\
\text { \& Goldsmith } \\
\text { (2013) }\end{array}$ & $\begin{array}{l}\text { Southeast } \\
\text { Region }\end{array}$ & $\begin{array}{l}\text { Consumer values (e.g., satisfaction and pride redeeming coupons) were linked } \\
\text { with coupon use. Did not include demographics in their model. }\end{array}$ \\
\hline $\begin{array}{l}\text { Noble et al., } \\
\text { (2017) }\end{array}$ & Panel data (US) & $\begin{array}{l}\text { Low-income consumers used more coupons than other income classes. Age and } \\
\text { the presence of children were positively linked with coupon use. }\end{array}$ \\
\hline $\begin{array}{l}\text { Lalwani \& } \\
\text { Wang (2019) }\end{array}$ & Panel data (US) & $\begin{array}{l}\text { Ethnicity (e.g., Asians and Indians) and values (e.g., interdependence) were } \\
\text { associated with more coupon use. }\end{array}$ \\
\hline
\end{tabular}

\section{SURVEY METHODOLOGIES}

Two rural communities were selected for this research. A community in Minnesota, labeled "M," is a county seat, is located near where three rural counties intersect, and is the largest city in the tri-county area. Community $\mathrm{M}$ had three supermarkets during the first survey. Like in many markets, the supermarkets in this city had used bonus couponing promotions. These promotions had ended before the first survey was conducted. One supermarket closed before the second survey was conducted. A WalMart Supercenter also opened in the community during 2007. Households from all three counties shop in 
community M. The population of the three rural counties was 39,186 in 1980 and 30,138 in 2010 , a decline of 23 percent.

To confirm the findings from community M, a Michigan community, labeled "P," was also surveyed. It is a county seat and is near the middle of a county that is geographically about 40 percent larger than any of the three Minnesota counties. This county had some development on the eastern and western edges, but the center of the county was primarily agricultural. Nearly all community P shoppers would be drawn from the rural parts of the county. Community $\mathrm{P}$ had two supermarkets and a WalMart Supercenter. This county's population increased from 66,814 in 1980 to 76,258 in 2010, with nearly all the growth occurring at the borders.

A 19-question survey was developed and pretested with a group of students. It included demographics and other questions from industry research published prior to 1985. Because it was a store intercept survey, the questionnaire needed to be short and easy to answer. The questions used in all five surveys were very similar. Response categories with dollar figures (e.g., savings from coupons per shopping trip, weekly grocery spending, and household income) were adjusted for inflation that occurred during the 28 years covered by the study (i.e., dollar-denominated categories were shifted up).

The first survey was conducted in community M during 1984. During two, high-volume shopping days, one of the authors or a trained student invited every other supermarket shopper entering the store to participate. Store intercept surveys usually produce samples that are reasonably representative and are similar in quality to telephone surveys (Bush \& Hair, 1985). Invited customers could complete the survey in the store and drop it in a box at the exit door. A total of 425 people completed at least one survey question. These results will be labeled "M84."

Two surveys were conducted in 1999, one in community $M$ during the summer and the other in community P during the fall. The community $\mathrm{M}$ store had moved across the road and had new owners. To improve the response rate, shoppers who refused to answer the survey in-store were offered a copy they could mail back with an addressed, stamped envelope. About 490 shoppers were asked to participate in the survey (i.e., every other shopper with two days). About 283 completed the survey in-store and 105 envelopes were distributed. The envelope option added 46 responses, raising the response rate to 67.1 percent. The results from this survey will be labeled "M99." In community P, a total of 287 people completed at least part of the survey in-store or mailed it back. This survey will be labeled "P99."

During fall 2011, the survey was repeated in community P with the envelope option. The P99 location had closed and a new supermarket near the former store was used. Survey responses for P11 totaled 361, a 73.2 percent response rate.

During spring 2012, the survey was repeated in community M with the envelope option. The ownership of the supermarket had changed again. Customer traffic during the survey was surprisingly low (this store has since closed). To boost the sample size, one author continued the survey during the next week for two days in the smaller, competing supermarket in community $\mathrm{M}$. The responses from shoppers at both stores totaled 228 , a 64.6 percent response rate.

The economic conditions during the surveys could be important because economic downturns tend to stimulate coupon use (DeNitto, 1992; Neff, 2010). At the time of the 1984 survey, the unemployment rate for the tri-county (M) area was about 5.9 percent, slightly below the state average, and it declined to 5.1 percent in 1999 and to 4.3 percent in 2012. These economic improvements could have reduced coupon interest. The unemployment rate for the county containing community P was 3.8 percent in 1999 and was 11.5 percent in 2011, which could have increased coupon popularity.

\section{RESULTS FROM THE SURVEYS}

The average responses to several questions across the five surveys are shown in Table 2 . The first question asked people if they liked coupons very much, liked coupons slightly, or disliked coupons. Between 80 and 90 percent of the respondents liked coupons either very much or slightly. The next question asked if they had used any coupons in recent months. The usage levels from the five surveys were higher than the national surveys, perhaps due to differences in the survey modes. 
The mean number of coupons redeemed during an average shopping trip ranged from 3.30 to 4.34 and was fairly stable across the five surveys. The survey also asked about shopping trip frequency, so it is possible to convert coupons per shopping trip into coupons per week. In the Nielsen 1984 survey, about 25 percent of all shoppers ( 32 percent of coupon users) redeemed five or more coupons per week. In survey M84, 52.7 percent of coupon users said they redeemed five or more per week, higher than the national result. The Manufacturers Coupon Center 1988 survey found that 29 percent of coupon users redeemed nine or more per week. In survey M99, 21.6 percent redeemed nine or more per week. In survey P99, 24.8 percent redeemed nine or more per week. These two surveys suggest that there were fewer heavy redeemers in these rural markets than at the national level in 1988, perhaps because shoppers had less access to coupons.

The mean coupon savings per shopping trip increased by 290 percent during the survey period. Respondents chose one of 11 classes that represented their coupon savings. The averages were calculated using the middle of each class range. Nationally, the average face value of redeemed coupons increased about 292 percent, from \$0.329 in 1984 to \$1.29 in 2011 (Nielsen Clearing House estimates). Active searching for coupons in the rural markets tended to be higher in community M. However, both communities had less active searching than the averages from 1980 and 1988 national surveys. The average times spent clipping and sorting coupons were relatively stable across the five surveys. Avery and Haynes (1991) asked their sample (from one city) about the time spent clipping coupons, and their average was higher than the survey results. The mean number of shopping trips per month ranged from 6.7 and 7.6 in the surveys, which is similar to the national norm of about eight grocery-shopping trips per month during this period. Table 2 also shows user opinions on how prices would change if coupons were eliminated. If those who believed a coupon ban would lower prices are assumed to be coupon critics, the five surveys suggest that coupon criticism had declined in these markets. The M84 survey was above average while the other surveys were below the national levels.

TABLE 2

\section{AVERAGE SCORES FROM THE FIVE SURVEYS}

\begin{tabular}{|c|c|c|c|c|c|}
\hline Survey Question & $\underline{\text { M84 }}$ & $\underline{\text { M99 }}$ & $\underline{\text { P99 }}$ & $\underline{P 11}$ & $\underline{\mathrm{M} 12}$ \\
\hline$\%$ who Like Coupons Very Much & 58.9 & 50.3 & 42.4 & 51.1 & 59.8 \\
\hline \% who Like Coupons Slightly & 29.7 & 33.7 & 40.3 & 38.3 & 30.8 \\
\hline$\%$ who Used Coupons & 90.9 & 88.8 & 87.7 & 86.1 & 86.7 \\
\hline Mean Number of Coupons Used per Shopping Trip & 3.88 & 3.50 & 4.29 & 3.30 & 4.23 \\
\hline $\begin{array}{l}\text { Mean Coupon Savings per Shopping Trip (Using the Middle of } \\
\text { Each Class) in Dollars }\end{array}$ & 1.71 & 3.82 & 4.38 & 5.27 & 6.67 \\
\hline$\%$ of Users who Actively Search for Coupons & 33.6 & 34.7 & 23.0 & 26.3 & 35.1 \\
\hline $\begin{array}{l}\text { Mean Time Spent per Week Clipping and Sorting Coupons (Using } \\
\text { the Middle of Each Class) in Minutes }\end{array}$ & 11.7 & 9.8 & 9.2 & 10.8 & 12.2 \\
\hline Mean Shopping Trips per Month & 6.87 & 7.16 & 7.52 & 7.13 & 6.77 \\
\hline $\begin{array}{l}\% \text { of Users who Said If Coupons were Eliminated, Prices would } \\
\text { be Lower }\end{array}$ & 24.1 & 13.2 & 18.4 & 12.3 & 14.3 \\
\hline $\begin{array}{l}\% \text { of Users who Said If Coupons were Eliminated, Prices would } \\
\text { Stay the Same }\end{array}$ & 46.8 & 45.4 & 52.9 & 46.8 & 45.3 \\
\hline $\begin{array}{l}\% \text { of Users who Said If Coupons were Eliminated, Prices would } \\
\text { be Higher }\end{array}$ & 5.4 & 9.3 & 4.5 & 6.7 & 7.2 \\
\hline Sample Size & 425 & 329 & 287 & 361 & 228 \\
\hline
\end{tabular}

The data from the five surveys suggests that the consumers in the two communities like coupons and may have become less critical of them. Avery and Haynes (1996) concluded that economic rationality is the main appeal of coupons for consumers, so those who have the potential to save more will tend to actively search and spend more time on them. Respondents in the two communities were less likely to actively search for coupons, spent less time clipping and sorting, and saved less money with coupons, 
probably because of lower coupon availability. The next section tests the contribution from liking coupons, active searching for coupons, and expecting prices to be lower without coupons along with demographics for predicting usage.

Linear regressions were used to examine the contribution of attitude and demographic measures for predicting the number of coupons redeemed per shopping trip. Because differences could exist between time periods and markets, separate regressions were used. Only respondents who said they redeemed coupons were included in the analyses. The regression fits, measured by the adjusted R-squares, were low, which is common in cross-section analyses.

In three of the regressions, liking coupons very much was significantly (95 percent confidence) and positively related to the number of coupons redeemed per shopping trip (Table 3). Consumers in M84 and M99 redeemed about 1.3 more coupons if they liked them very much. The coefficient was larger in P99, suggesting those shoppers who liked coupons very much redeemed 3.2 more coupons. This attitudinal variable was not significant in P11 and M12, which suggests that a shift may have occurred between 1999 and 2011. The change in the economic conditions might explain the result for M12 but not for P11. Perhaps coupon users in both areas had become more neutral about couponing, but still redeemed them or younger users did not feel as positively about coupons as older users.

Active searching became more important during the survey period, generating about 1.3 more redemptions per shopping trip in M84 and nearly four more coupons in P11 and M12. The belief that prices would be lower if coupons were eliminated was not significantly related to coupon use. Perhaps this measure of coupon criticism did not influence shopper willingness to use them.

Several demographics were not significant in most of the regressions. Although some surveys linked education with coupon use (e.g., Bawa \& Shoemaker, 1987; Meloy, McLaughlin \& Kramer, 1988), the college-degree variable coefficients were not significant at the 95 percent confidence level. Gender was significant in several studies (e.g., Avery \& Hayes, 1992; Meloy, McLaughlin \& Kramer, 1998; Park \& Gomez, 2004). However, it was not significant in this research. Marital status and income were significant in a few studies. However, being single and having an income in the middle or high categories were only associated with redeeming significantly fewer coupons in M12.

The remaining three measures, household size, age, and shopping frequency, were significantly related to coupon use in some prior research. Some studies found a positive relationship between household size and coupon use (e.g., Meloy, McLaughlin \& Kramer, 1988; Goodwin, 1992) and others did not (e.g., Bawa \& Shoemaker, 1987; Avery \& Haynes, 1992; Cronovich, Daneshvary \& Schwer, 1997). Relative to households with one or two members, larger households in M84 redeemed more coupons. Households with five or more members redeemed significantly more coupons in the P99 and M12 surveys, but not in the two other surveys.

Younger respondents (age 18 to 34) redeemed more coupons in three of the surveys. Age was mentioned in the industry profiles and was significant in the four of the studies in Table 1. However, prior studies differed in whether younger or middle-aged respondents redeemed more coupons. In this research, the younger age class had significant, positive coefficients in P99, P11, and M12.

Shopping frequency was identified as important by Noble, Lee, Zaretzki, and Autry (2017). This behavior variable could be an indirect measure of shopper organization. Those who shop less often may plan their shopping trips and could include coupons in their planning. The hypothesized negative coefficient on the shopping frequency variable was noted in all the regressions. However, this variable was only significant in the M84 regression. 


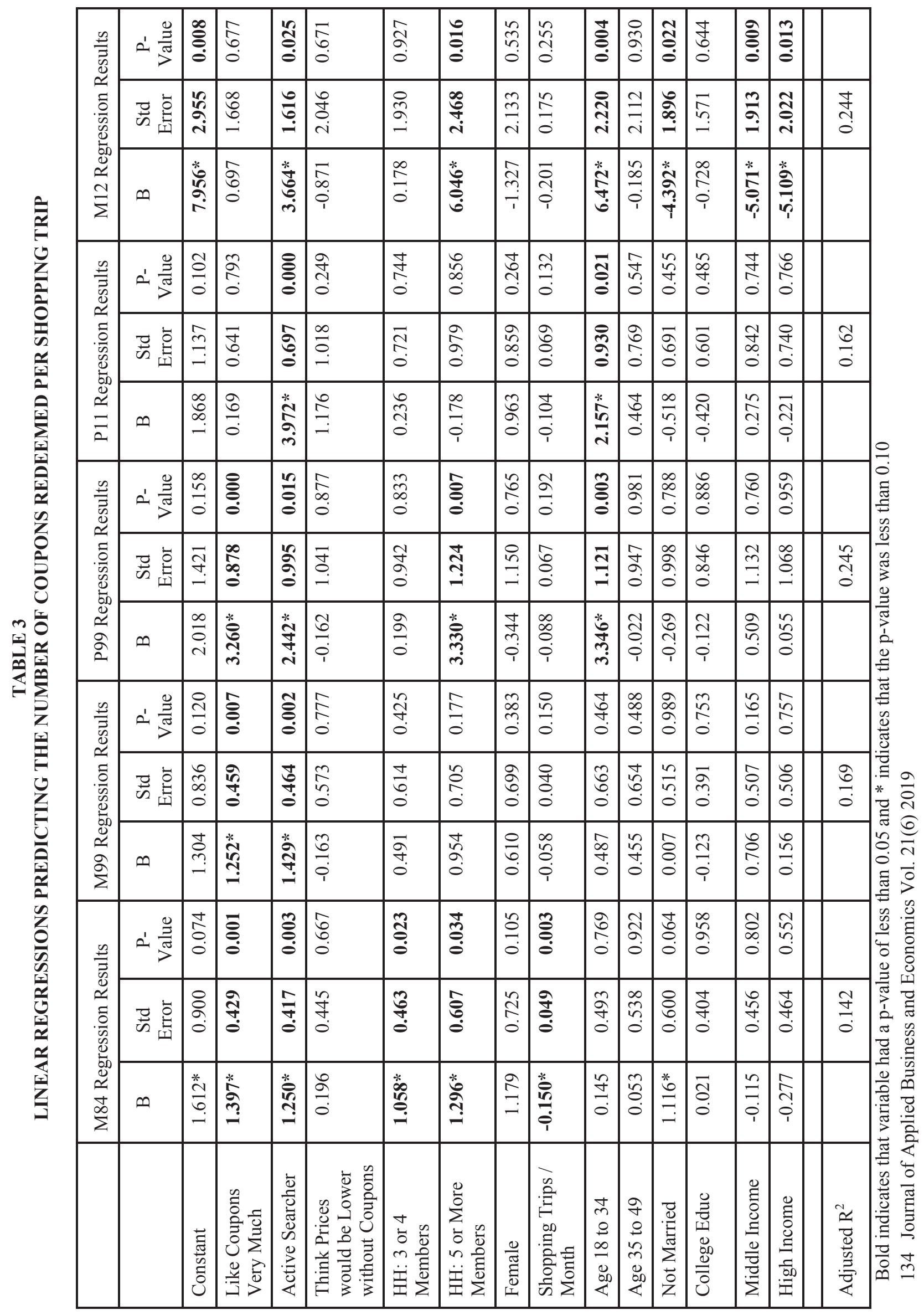


Changes in the coupons received could have contributed to the variations over time. The increase in multiple purchase requirements may have shifted use toward larger households who have higher consumption rates. Changes in the mix of products promoted with coupons could also increase usage among younger respondents with several children. For example, Kantar Media (2005; 2007; 2010; 2013) estimated that the annual distribution of FSI coupons for diapers increased from 2.46 billion in 2004 to 4.27 billion in 2009 and FSI coupons for baby wipes increased from 0.57 billion in 2005 to 2.07 billion in 2011. Between 2004 to 2011, the total FSI coupon distribution only increased by 8.7 percent. The growth in baby product coupons could have made coupons more popular among young families. The shifts in the mix of coupons and the changes in the purchase requirements could have affected usage profiles in the rural areas.

\section{GENERAL DISCUSSION}

The evidence suggests that the gap in coupon distribution between urban and rural markets grew in the late 1980s as scanning data became more important for marketing decisions. The five intercept surveys, conducted in this research, were used to explore why the gap between urban and rural markets has continued.

The first question examined by the surveys was who redeems coupons in rural areas. A high proportion of rural shoppers used coupons. Younger shoppers and larger households were more likely to redeem more coupons in three of the surveys. Because rural markets received fewer coupons, residents probably saw less potential savings from coupons and were less likely to actively search for them. Active searching was an important predictor of the number of coupons redeemed per week and was below the national norm in both communities. There were also fewer heavy redeemers. This could reflect having fewer coupons available to redeem.

The second question addressed by the surveys was if coupon attitudes or use changed. The proportions who liked coupons and who used them remained fairly constant as was the number of coupons redeemed per shopping trip and the time spent clipping and sorting. National data suggested that these measures were probably rising. The savings from coupons increased by roughly the same percentage as the average face value of coupons. In the regressions, liking coupons very much became less important while shoppers aged 18 to 34 became significant coupon users. Household size may be an important variable that can help predict coupon usage. In total, only a few changes were noted during the 28 years covered by these surveys.

The last question was if attitudes or behaviors involving coupons were different in rural areas. Although it is difficult to compare coupon user profiles in rural and urban areas, no serious discrepancies between rural and urban users were noted. The demographic measures were not significant in every regression. Contrary to the assumption by early surveys and consistent with other recent research, this analysis found that demographics were not good predictors of coupon usage. The attitude of liking coupons was significant in three regressions. The behavior of actively searching was an important predictor of coupon use.

\section{IMPLICATIONS FOR PRACTICE}

This research did not uncover any consumer-based reasons why some manufacturers continue to distribute fewer FSI coupons in rural markets. The percentage using coupons was high in the rural communities and many people liked them. Behaviors associated with coupon availability (e.g., active searching, heavy redeemers) were lower in rural markets that the national norms. If coupons are profitable marketing tools, the lower coupon clutter in rural markets would probably boost the efficiency of coupon events in these areas. As a marketing communication tool, coupons could help build brands and boost sales in rural areas. Manufacturers may have started this practice when scanning data became more important for marketing decisions during the mid-1980s. Marketers should examine their market distribution lists and consider expanding their coupon distribution in rural markets. 
One limitation with this research is that the two surveyed communities were not representative of all rural markets. For example, in 1980 and 1990, 99 percent of community M was white. Community M was 97 percent white in 2000 and 92 percent white in 2010. Community P was 88 percent white in 2000 and 87 percent white in 2010. Several studies have linked ethnicity to coupon use. Coupon redemptions also tend to be higher in some regions of the country (based on the experience of one author). Therefore, replicating this research in rural areas that are more diverse and in different parts of the US could be helpful.

Another limitation is that the statistical model fits were relatively low, suggesting that future research should test other variables. These could include attitude measures (e.g., time preferences, price consciousness, newspaper readership, enjoyment from redeeming coupons, brand loyalty, embarrassment from redeeming coupons, etc.) and variables that were suggested in other studies (e.g., ages of children in household, number of employed individuals in household, number of hours worked per week, use of mobile payment systems, participation in store loyalty programs, recall of parents redeeming coupons, etc.). The evidence seems to suggest that manufacturers may still be using market distribution lists from the 1980s for their coupon events. The surveys showed that rural residents liked and used coupons and would probably redeem more if coupon distribution was increased in rural markets.

\section{ACKNOWLEDGMENT}

This research was partially supported by the Minnesota Experiment Station (Grant number MIN 14040). 


\section{REFERENCES}

Avery, R. J., \& Haynes, G. W. (1991). Coupons: Boon or boondoggle for consumers? Human Ecology Forum, 19, 13-16.

Avery, R. J., \& Haynes, G. W. (1992). Coupons: Are the savings an illusion? Advancing the Consumer Interest, 4(2), 13-18.

Avery, R. J., \& Haynes, G. W. (1996). Estimation of consumer savings from coupon redemption. Journal of Managerial Issues, 8(4), 405-424.

Bawa, K., \& Shoemaker, R.W. (1987). The coupon-prone consumer: Some findings based on purchase behavior across product classes. Journal of Marketing, 51(4), 99-110.

Bucklin, R.E., \& Gupta, S. (1999). Commercial use of UPC scanner data: Industry and academic perspectives. Marketing Science, 18(3), 247-273.

Bush, A. J., \& Hair, J. F. Jr. (1985). An assessment of the mall intercept as a data collection method. Journal of Marketing Research, 22(2), 158-167.

Clark, R. A., Zboja, J. J., \& Goldsmith, R. E. (2013). Antecedents of coupon proneness: A key mediator of coupon redemption. Journal of Promotion Management, 19(2), 188-210.

Colombo, R., Bawa, K., \& Srinivasan, S. S. (2003). Examining the dimensionality of coupon proneness: A random coefficients approach. Journal of Retailing and Consumer Services, 10(1), 27-33.

CMS. (1993). Consumer Study: Reaching Consumers with Coupons. Winston-Salem, NC: CMS.

CMS. (1996). Consumer Study. Winston-Salem, NC: CMS.

Cronovich, R., Daneshvary, R., \& Schwer, R. K. (1997). The determinants of coupon usage. Applied Economics, 29(12), 1631-1641.

DeNitto, E. (1992). Coupon redemption gets a boost from recession. Supermarket News, 24, 13.

Deveny, K., \& Gibson, R. (1994, May 10). Awash in coupons? Some firms try to stem the tide. Wall Street Journal, B1, B10.

Gibson, R. (1991, March 22). Marketers' mantra: Reap more with less. Wall Street Journal, B1-B2.

Goodwin, B. K. (1992). An analysis of factors associated with consumers' use of grocery coupons. Journal of Agricultural and Resource Economics, 17(1), 110-120.

Kantar Media. (2005). 2004 Free Standing Insert Distribution Trends. Minneapolis, MN: Kantar Media. Kantar Media. (2007). 2006 Free Standing Insert Distribution Trends. Minneapolis, MN: Kantar Media. Kantar Media. (2010). 2009 Free Standing Insert Distribution Trends. Minneapolis, MN: Kantar Media. Kantar Media. (2013). 2012 Free Standing Insert Distribution Trends. Minneapolis, MN: Kantar Media. Kantar Media. (2016). 2015 Free Standing Insert Distribution Trends. Minneapolis, MN: Kantar Media.

Lalwani, A. K., \& Wang, J. J. (2019). How do consumers' cultural backgrounds and values influence their coupon proneness? A multi-method investigation. Journal of Consumer Research, 45(5), 1037-1050.

Larson, R. B. (1991). Coupons are more than price discounts. Paper presented at the TIMS Marketing Science Conference in Wilmington, DE.

Larson, R. B. (1992). Marketing agricultural products with coupons. Agribusiness, 8(5), 485-492.

Larson, R. B. (1994). Discount coupons: Beyond the price discount effect. In Promotion in the Marketing Mix: What Works, Where and Why. Proceedings from the NEC-63 Conference in Toronto, Canada, 42-52.

Lipman, J. (1987, February 3). Firms bid to cut sales coupons, other incentives. Wall Street Journal, 35.

Lipman, J. (1989, June 26). Too many coupons in the paper? Advertisers rethink promotion. Wall Street Journal, B4.

Manufacturers Coupon Center. (1989). The Impact of Coupons on Consumer Purchase Decisions. Clinton, IA: A. C. Nielsen Company.

Meloy, M. G., McLaughlin, E. W., \& Kramer, C. S. (1988). Consumer Segmentation Analysis of Grocery Coupon Users. Department of Agricultural Economics, Cornell University Agricultural Experiment Station, New York State College of Agriculture and Life Sciences, A.E. Res 88-17. 
Mittal, B. (1994). An integrated framework for relating diverse consumer characteristics to supermarket coupon redemption. Journal of Marketing Research, 31(4), 533-544.

Mooty, C. S. (1982). Survey of Arkansas households shows family life cycle affects coupon use. Arkansas Farm Research, 31(6), 13.

Narasimhan, C. (1984). A price discrimination theory of coupons. Marketing Science, 3(2), 128-147.

NCH. (2009). 2009 NCH Consumer Survey: Demographic Profile of Coupon Users. Livonia, MI: Valassis.

NCH. (2013). 2013 Valassis Shopper Marketing Survey: Demographic Profile of Coupon Users. Livonia, MI: Valassis.

NCH Marketing Services. (2019). NCH year-end 2018 coupon facts: At a glance. Retrieved July 1, 2019, from https://www.nchmarketing.com/CouponIndustryTrends.aspx.

Neff, J. (2010). Coupon clipping stages a comeback. Advertising Age, 81(39), 1, 26.

Newspaper Advertising Bureau. (1985). Coupon Facts, 1985. New York, NY: Newspaper Advertising Bureau, Inc.

Newspaper Advertising Bureau. (1987). Coupon Facts, 1987. New York, NY: Newspaper Advertising Bureau, Inc.

Nielsen Clearing House. (1980). Coupons: The Consumer Speaks Out. Clinton, IA: A.C. Nielsen Company.

Nielsen Clearing House. (1985). What Consumers Think of Coupons. Clinton, IA: A.C. Nielsen Company.

Nigut, W. Sr. (1981). The case against coupons. Progressive Grocer, 60(5), 7-8.

Noble, S. M., Lee, K. B., Zaretzki, R., \& Autry, C. (2017). Coupon clipping by impoverished consumers: Linking demographics, basket size, and coupon redemption rates. International Journal of Research in Marketing, 34(2), 553-571.

NPD Group. (1986). The NPD Dimension: Deriving Knowledge from Information. New York, NY: NPD Group.

Park, K., \& Gomez, M. I. (2004). Predicting coupon use from shopper demographic and behavioral characteristics. Journal of Food Distribution Research, 35(1), 162-168.

Promotion Decisions. (1997). Understanding the Financial Efficiency and Effectiveness of FSI Coupons. Cincinnati, OH: Promotion Decisions, Inc.

Slater, J. (2001). Is couponing an effective promotional strategy? An examination of the Procter and Gamble zero-coupon test. Journal of Marketing Communications, 7(1), 3-9.

Trump, R. K. (2016). Harm in price promotions: When coupons elicit reactance. Journal of Consumer Marketing, 33(4), 302-310.

Uhl, J. N. (1982). Cents-off coupons: Boon or boondoggel for consumers? Journal of Consumer Affairs, 16(1), 161-165.

Valassis. (2018). Modern Shoppers and Their Quest for Savings. Livonia, MI: Valassis. 